CASE REPORT

\title{
Radial forearm free flap morbidity: A rare case of a normal preoperative arteriogram and acute intraoperative hand ischemia
}

\author{
Terrence W Bruner MD MBA ${ }^{1}$, Matthew M Hanasono MD², Roman J Skoracki MD²
}

TW Bruner, MM Hanasono, RJ Skoracki. Radial forearm free flap morbidity: A rare case of a normal preoperative arteriogram and acute intraoperative hand ischemia. Can J Plast Surg 2011;19(3):102104.

Since its first description in 1981, the radial forearm free flap has become a valuable tool for reconstructive microsurgery. However, there are potential complications associated with the flap - the most feared being hand ischemia from sacrifice of the radial artery. Fortunately, acute ischemic complications are exceedingly rare, with only two cases reported in the literature. Options for preoperative evaluation of the donor extremity include the Allen's test, ultrasonography and angiography. A preoperative arteriogram is considered to be the definitive method to evaluate arterial anatomy, patency, and collateralization between the radial and ulnar arteries. The current article presents the authors' experience with a patient who had a delayed Allen's test and a normal arteriogram of his left upper extremity, and who developed acute intraoperative hand ischemia, requiring reconstruction of his radial artery, after elevation of a radial forearm free flap. Although exceedingly rare, the occurrence of acute vascular insufficiency is always a possibility and must be kept in mind when harvesting a radial forearm free flap. The surgeon should be prepared to perform an interposition vein graft reconstruction to avoid any potential complications. Clinical examination and judgment may be more important than radiological studies in certain cases.

Key Words: Angiogram; Hand ischemia; Radial forearm free flap; Vein graft

Since its initial description in 1981 (1), and subsequent introduction in the western medical literature soon thereafter (2), the radial forearm free flap has become a valuable tool for reconstructive microsurgery. Flap characteristics include thin, pliable fasciocutaneous tissue, a long vascular pedicle with vessels of large calibre, reliable anatomy, and relative ease and simplicity of flap elevation. One can also include osseous and muscle components, thereby adding chimeric options to the flap (3). While it has, to some extent, been supplanted by the free fibula for bone reconstruction, and the anterolateral thigh flap for larger soft tissue island and improved donor site morbidity, the radial forearm free flap remains an integral part of the head and neck, and upper extremity reconstruction armamentarium.

The most dreaded potential complication is acute hand ischemia from sacrifice of the radial artery. Remarkably, only two cases of acute hand ischemia have been reported: one following elevation of a radial forearm free flap (4) and another from harvest of the radial artery for coronary artery bypass grafting (5). Delayed hand ischemia associated with smoking has also been reported $(6,7)$. This is an indication that ischemic complications are an exceedingly rare occurrence; however, relative hypoperfusion manifested as cold intolerance may persist.

Attempts have been made to establish algorithms for preoperative evaluation of donor extremities before free flap harvesting (8). Traditionally, the Allen's test has been used as an inexpensive, rapid, noninvasive method to evaluate dual arterial patency and vascular communication to ensure hand perfusion (9), and to identify those at

\author{
La morbidité d'un lambeau radial libre de \\ l'avant-bras : un rare cas d'artériogramme \\ préopératoire normal et d'ischémie \\ intraopératoire aiguë de la main
}

\begin{abstract}
Depuis la première fois où il a été décrit en 1981, le lambeau radial libre de l'avant-bras est devenu un outil précieux de la microchirurgie reconstructive. Cependant, des complications potentielles s'y associent, celui qu'on craint le plus étant l'ischémie de la main découlant du sacrifice de l'artère radiale. Heureusement, les complications ischémiques aiguës sont d'une extrême rareté, seulement deux cas ayant été déclarés dans les publications. Les possibilités d'évaluation préopératoire de l'extrémité du donneur incluent le test d'Allen, l'échographie et l'angiographie. L'artériogramme préopératoire est considéré comme la meilleure méthode pour évaluer l'anatomie artérielle, la perméabilité et la collatéralisation entre les artères radiale et ulnaire. Le présent article expose l'expérience des auteurs auprès d'un patient qui a subi un test d'Allen tardif et un artériogramme de l'extrémité supérieure gauche et qui a développé une ischémie intraopératoire aiguë de la main, laquelle a exigé une reconstruction de l'artère radiale après l'élévation d'un lambeau radial libre de l'avant-bras.

Même si elle est d'une extrême rareté, l'occurrence d'une insuffisance vasculaire aiguë est toujours possible, et il faut l'avoir à l'esprit lorsqu'on prélève un lambeau radial libre de l'avant-bras. Le chirurgien doit être prêt à exécuter une reconstruction par interposition d'une greffe veineuse afin d'éviter les complications potentielles. Dans certains cas, l'examen clinique et le jugement ont peut-être plus d'importance que les études radiologiques.
\end{abstract}

risk for distal ischemia following sacrifice of the radial artery. The Allen's test is performed by simultaneously compressing both the ulnar and radial arteries at the wrist, while the patient actively exsanguinates his/her hand. This manoeuvre is followed by active extension of the fingers and subsequent release of one of the arteries. Hand reperfusion, as documented by brisk capillary refill in less than $5 \mathrm{~s}$, is considered to be a normal study. If hand ischemia is a concern based on an abnormal or delayed Allen's test, additional studies, including duplex ultrasound and angiography of the extremity, can be obtained. Duplex ultrasonography has been used to predict the safety of sacrificing the radial artery in the presence of an abnormal Allen's test (10). Obtaining an arteriogram is more problematic. Preoperative angiography of the donor extremity is expensive, invasive and unnecessary if performed on a routine basis. It also places the patient at additional risk for significant complications including arterial occlusion, aortic dissection, renal failure, hematoma, intimal damage and contrast-induced anaphylactic reaction (8). Nevertheless, arteriography is considered to be an ideal technique for evaluating arterial anatomy, patency and collateralization between the radial and ulnar arteries (8). The present report describes our experience at The University of Texas MD Anderson Cancer Center (USA) involving a patient who had a delayed Allen's test and a normal arteriogram of his left upper extremity, and who subsequently went on to develop acute intraoperative hand ischemia, requiring immediate reconstruction of his radial artery after elevation of a radial forearm free flap.

${ }^{1}$ University Medical Group, Greenville Hospital System, Greenville, South Carolina; ${ }^{2}$ Division of Plastic Surgery, The University of Texas MD

Anderson Cancer Center, Houston, Texas, USA

Correspondence: Dr Roman J Skoracki, Division of Plastic Surgery, The University of Texas MD Anderson Cancer Center, 1515 Holcombe

Boulevard, Unit 443, Houston, Texas 77030, USA. Telephone 713-794-1247, fax 713-794-5492, e-mail rjskoracki@mdanderson.org 


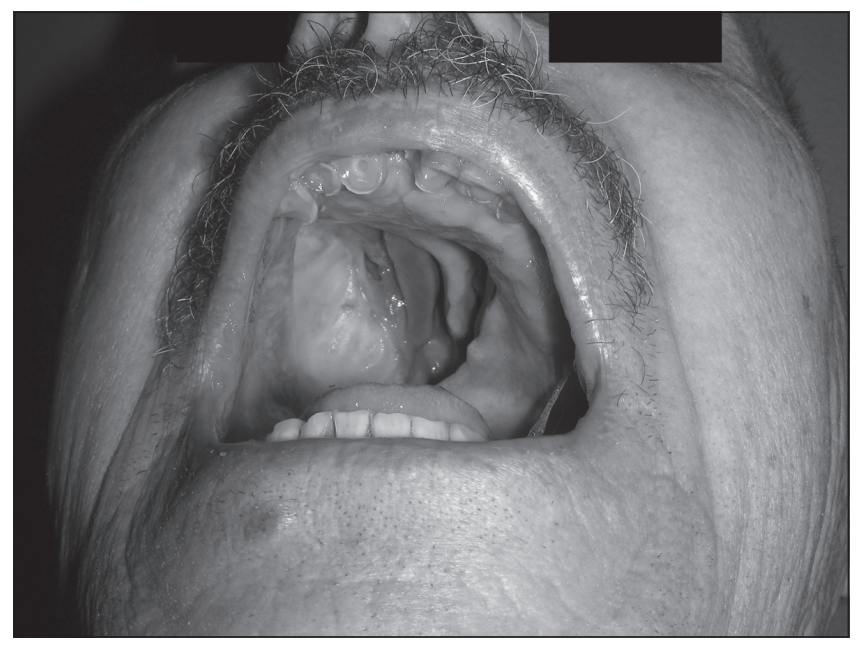

Figure 1) Preoperative view of the oronasal fistula

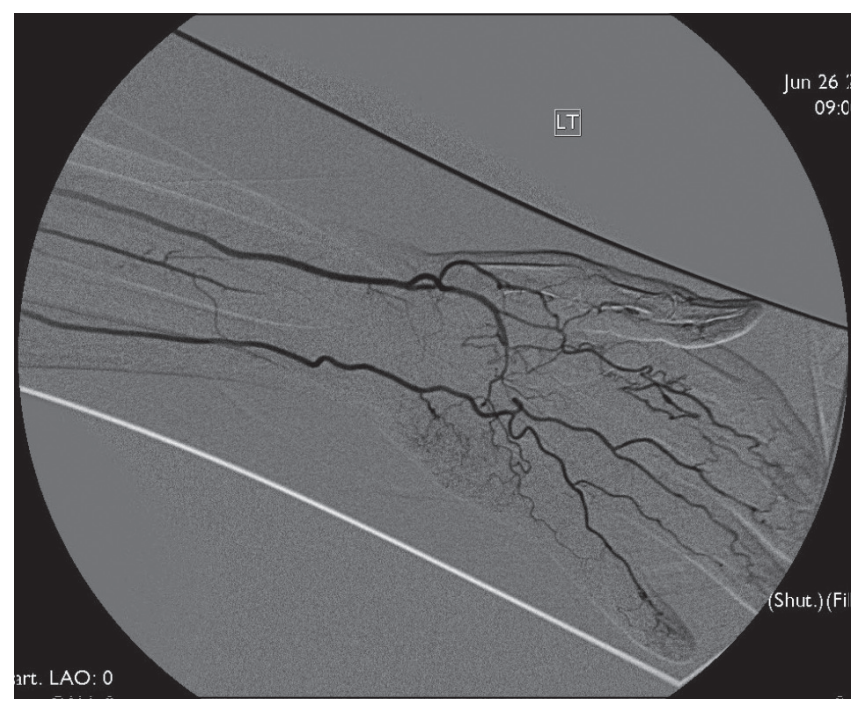

Figure 2) Arteriogram demonstrating the patent palmar arch

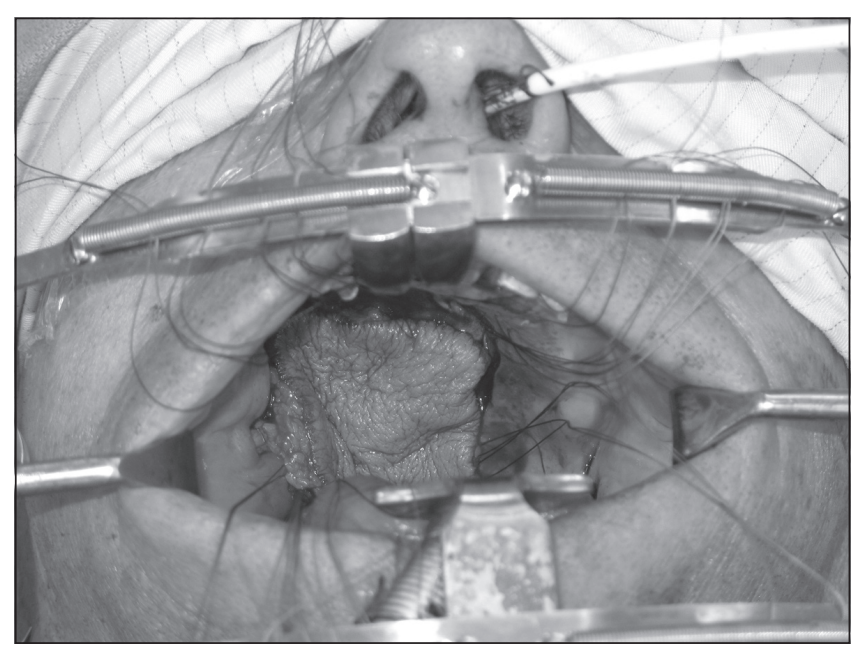

Figure 3) Intraoperative view of the radial forearm free flap inset

\section{CASE PRESENTATION}

The patient was a 73-year-old right-hand dominant man with a history of papillary adenocarcinoma to his hard palate that was resected without reconstruction (Figure 1). He functioned well with an obturator for his hard palatal defect for more than a decade and remained disease

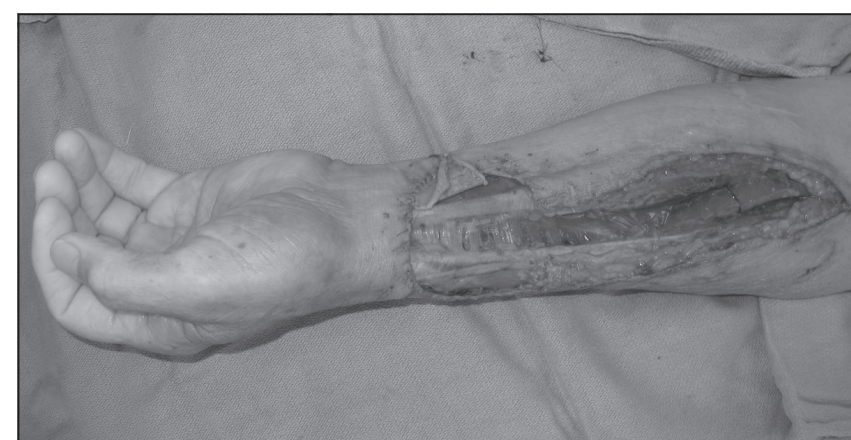

Figure 4) Intraoperative view of the radial forearm free flap harvest site and acutely ischemic left hand

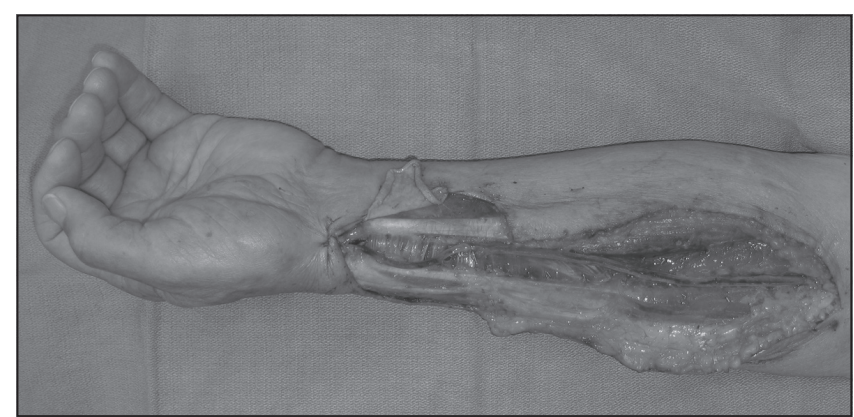

Figure 5) Intraoperative view of the reperfused left hand with interposition saphenous vein graft in place

free. However, over time, he began to develop recurrent ulcerations and loosening of his anterior dentition. With impending inability to retain his obturator and the subsequent risk of severe functional disability from his large oronasal fistula, he was referred to the MD Anderson Cancer Center for evaluation regarding reconstructive options. A radial forearm free flap was planned to reconstruct his palatal defect. Because his medical history was significant for smoking, myocardial infarction and signs of peripheral vascular disease on examination, including a mildly delayed Allen's test (5 s), a left upper extremity arteriogram was obtained preoperatively. The angiographic results documented patency of his palmar arches (Figure 2). Intraoperatively, a fasciocutaneous radial forearm flap was elevated from the left upper extremity to reconstruct the intraoral defect (Figure 3). After inset of the free flap, the hand was examined and noted to be pale and cold, with lack of capillary refill, particularly to the thumb and radial aspect (Figure 4). Surgical clips were removed from the stump of the distal radial artery, which confirmed the absence of arterial backflow. A reverse saphenous vein interposition graft was used to reconstruct the segmental arterial defect, with resultant reperfusion of the hand (Figure 5). A skin graft was then applied to the volar forearm soft tissue defect after appropriate skin and muscle coverage of the vein graft. The patient subsequently had an uneventful postoperative recovery, with no functional deficits of the hand. During his long-term (two years) follow-up period, the patient's forearm remained well healed and stable (Figure 6). Currently, his hand is well perfused and he has a palpable radial arterial pulse at the wrist ( 2.5 years postoperatively).

\section{DISCUSSION}

The acute hand ischemia that was encountered intraoperatively would have been less of an issue if reconstruction of the radial artery was an intended integral part of the surgical procedure. In fact, out of concern for possible risk of hand ischemia, it was initially recommended that vein graft reconstruction of the radial artery defect be performed on a routine basis following radial forearm flap elevation (11-13). However, on long-term follow-up, significant percentages (41\% to 46\%) of vein grafts for radial artery reconstruction were no longer patent (14-16); 
this finding led to extensive research evaluating the hemodynamic changes of the hand after sacrifice of the radial artery. It is now believed that vein grafting the radial artery defect on a routine basis is unnecessary (7,16-19). Vascular compensation develops after removal of the radial artery via the ulnar, posterior interosseous and anterior interosseous arteries; the overall perfusion of the hand is not affected $(20,21)$. In fact, various studies have evaluated the postoperative functional status of the donor extremity, and found no clinically significant difference in vascular perfusion $(2,17,18,20-26)$. Currently, vein graft reconstruction of the radial artery is rarely performed $(4,27)$, and should be reserved for acute intraoperative ischemia $(17,19)$.

While it has been deemed safe to harvest the radial artery on the basis of a normal Allen's test alone $(8,10,16)$, false-negative results may occur due to variations in arterial anatomy $(4,5)$. Consequently, sacrifice of the radial artery may result in acute hand ischemia despite a normal Allen's or Doppler ultrasound (28). The previously reported instances of acute hand ischemia occurred in individuals with apparently normal preoperative Allen's tests $(4,5)$, with adequate perfusion of the hand and the radial artery occluded. However, a delayed Allen's test should prompt the surgeon to investigate the vascular connection between the ulnar and radial systems more closely if no alternative flaps are available.

Based on this experience, if a radial forearm free flap is our preferred method of reconstruction and the patient presents with an abnormal Allen's test, we will use an alternative method of reconstruction, be it the opposite radial forearm or another fasciocutaneous flap, rather than rely on angiography results.

\section{REFERENCES}

1. Yang G, Chen B, Gao Y. Forearm free skin flap transplantation. Nat Med J China 1981;61:139-41.

2. Song R, Gao Y, Song Y, et al. The forearm flap. Clin Plast Surg 1982;9:21-6.

3. Mathes NJ, Nahai F, eds. Radial forearm flap. In: Reconstructive Surgery: Principles, Anatomy \& Technique. New York: Churchill Livingstone; 1997:775-802.

4. Jones BM, O'Brien CJ. Acute ischemia of the hand from elevation of a radial forearm flap. Br J Plast Surg 1985;38:396-7.

5. Nunoo-Mensah J. An unexpected complication after harvesting of the radial artery for coronary artery bypass grafting.

Ann Thorac Surg 1998;66:929-31.

6. Holzle F, Kesting MR, Nolte D, et al. Reversible ischemia after raising a radial forearm flap with ulceration of three fingers in a cigarette smoker. Br J Oral Maxillofac Surg 2006;44:57-9.

7. Heller F, Wei W, Wei FC. Chronic arterial insufficiency of the hand with fingertip necrosis 1 year after harvesting a radial forearm free flap. Plast Reconstr Surg 2004;114:728-31.

8. Ahmad N, Kordestani R, Panchal J, et al. The role of donor site angiography before mandibular reconstruction utilizing free flap. J Reconstr Microsurg 2007;23:199-203.

9. Allen EV. Thromboangiitis obliterans: Methods of diagnosis of chronic occlusive arterial lesions distal to the wrist with illustrative cases. Am J Med Sci 1929;178:237-44.

10. Abu-Omar Y, Mussa S, Anastasiadis K, et al. Duplex ultrasonography predicts safety of radial artery harvest in the presence of an abnormal Allen test. Ann Thorac Surg 2004;77:116-9.

11. Muhlbauer W, Herndl E, Stock W. The forearm flap. Plast Reconstr Surg 1982;70:336-42.

12. Brenner P, Berger A, Caspary L. Angiologic observations following autologous vein grafting and free radial artery flap elevation. J Reconstr Microsurg 1988;4:297-301.

13. Soutar DS, Scheker LR, Tanner NSB, et al. The radial forearm flap: A versatile method for intra-oral reconstruction. Br J Plast Surg 1983;36:1-8.

14. Boorman JG, Brown JA, Sykes PJ. Morbidity in the forearm flap donor arm. Br J Plast Surg 1987;40:207-12.

15. Gelberman RH, Nunley JA, Koman LA, et al. The results of radial and ulnar arterial repair in the forearm. J Bone Joint Surg Am 1982;64:383-7.

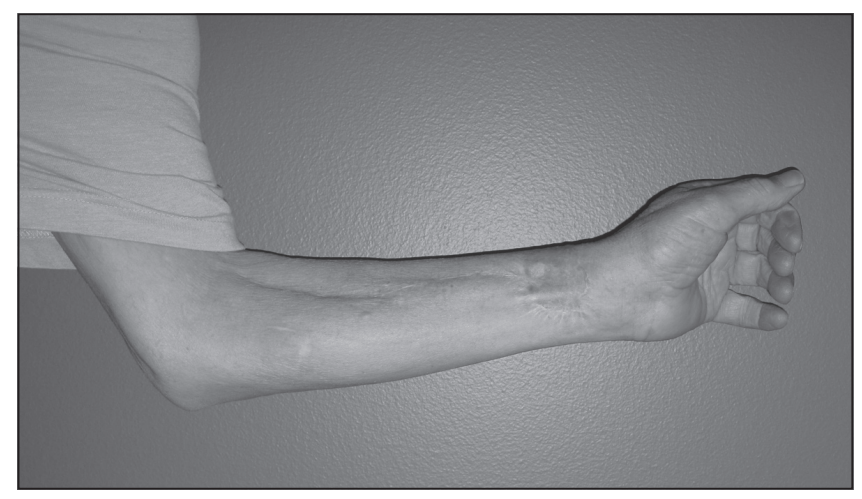

Figure 6) Postoperative donor site result (two years after surgery)

\section{CONCLUSION}

Although exceedingly rare, the occurrence of acute vascular insufficiency is always a possibility and must be kept in mind when harvesting a radial forearm free flap. In principle, the plastic surgeon should always have a 'lifeboat' (29), and should be prepared to perform a vein graft reconstruction to avoid any potential untoward intraoperative complications. Furthermore, regarding patient selection, peripheral vascular disease and smoking should be considered relative contraindications for the radial forearm free flap $(6,16-18)$. In the present case, clinical examination and judgment were more important and relevant than radiological studies.

16. Bardsley AF, Soutar DS, Elliot D, et al. Reducing morbidity in the radial forearm flap donor site. Plast Reconstr Surg 1990;86:287-94.

17. Meland BN, Core GB, Hoverman VR. The radial forearm flap donor site: Should we vein graft the artery? A comparative study. Plast Reconstr Surg 1993;91:865-70.

18. Richardson D, Fisher SE, Vaughan ED, et al. Radial forearm flap donor site complications and morbidity: A prospective study. Plast Reconstr Surg 1997;99:109-15.

19. Hallock GG. Reducing morbidity in the radial forearm flap donor site. Plast Reconstr Surg 1990;86:293-4.

20. Ciria-Llorens G, Gomez-Cia T, Talegon-Melendez A. Analysis of flow changes in forearm arteries after raising the radial forearm flap: A prospective study using colour duplex imaging. Br J Plast Surg 1999;52:440-4.

21. Talegon-Melendez A, Ciria-Llorens G, Gomez-Cia T, et al. Flow changes in forearm arteries after elevating the radial forearm flap: Prospective study using color duplex imaging. J Ultrasound Med 1999;18:553-8.

22. Lohr JM, Paget DS, Smith JM, et al. Upper extremity hemodynamic changes after radial artery harvest for coronary artery bypass grafting. Ann Vasc Surg 2000;14:56-62.

23. Suominen S, Ahovuo J, Asko-Seljavaara. Donor site morbidity of radial forearm flaps: A clinical and ultrasonographic evaluation. Scand J Plast Reconstr Hand Surg 1996;30:57-61.

24. Brodman RF, Hirsh LE, Frame R. Effect of radial artery harvest on collateral forearm blood flow and digital perfusion. J Thorac Cardiovasc Surg 2002;123:512-6.

25. Dumanian GA, Segalman K, Mispireta LA, et al. Radial artery use in bypass grafting does not change digital blood flow or hand function. Ann Thorac Surg 1998;65:1284-7.

26. Iida Y, Numata T, Shiba K, et al. Hemodynamic changes in the hand after radial forearm flap harvesting. Ann Plast Surg 2002;49:156-60.

27. Nuckols DA, Tsue TT, Toby EB, et al. Preoperative evaluation of the radial forearm free flap patient with the objective Allen's test. Otolaryngol Head Neck Surg 2000;123:553-7.

28. Ruengsakulrach P, Buxton BF, Eizenberg N, et al. Anatomic assessment of hand circulation in harvesting the radial artery. J Thorac Cardiovasc Surg 2001;122:178-80.

29. Millard DR. Principalization of Plastic Surgery. New York: Little, Brown and Co, 1986. 